\title{
PENGARUH PEMANFAATAN TEKNOLOGI INFORMASI, PEMAHAMAN SISTEM AKUNTANSI KEUANGAN DAERAH, KOMPETENSI SUMBER DAYA MANUSIA TERHADAP KUALITAS LAPORAN KEUANGAN DENGAN SISTEM PENGENDALIAN INTERN SEBAGAI VARIABEL INTERVENING PADA PEMERINTAH PROVINSI KEPULAUAN RIAU
}

\author{
Novi Chandra Saputra \\ Sekolah Tinggi Ilmu Ekonomi (STIE) Pembangunan Tanjungpinang \\ novi.chandra.saputra@gmail.com
}

\begin{abstract}
Abstrak: Penelitian ini bertujuan untuk menganalisis pengaruh pemanfaatan teknologi informasi, pemahaman sistem akuntansi keuangan daerah, kompetensi sumber daya manusia terhadap kualitas laporan keuangan serta untuk menguji dan menganalisis sistem pengendalian intern dalam memediasi hubungan antara pemanfaatan teknologi informasi, pemahaman sistem akuntansi keuangan daerah, kompetensi sumber daya manusia terhadap kualitas laporan keuangan. Penelitian ini menggunakan pendekatan kuantitatif. Jenis data yang digunakan dalam penelitian ini adalah data primer. Penelitian ini dilakukan menggunakan metode survei dengan menyebarkan kuisioner kepada pengelola keuangan daerah pada Pemerintahan Provinsi Kepulauan Riau. Populasi penelitian ini adalah pengelola keuangan pada 41 SKPD sebanyak 123 orang. Penentuan sampel melalui sampel jenuh (sensus). Data diolah dengan menggunakan aplikasi SEM-PLS versi 3.0. Hasil dari penelitian ini menunjukkan bahwa secara parsial pemanfaatan teknologi informasi, pemahaman sistem akuntansi keuangan daerah, kompetensi sumber daya manusia, sistem pengendalian intern berpengaruh signifikan terhadap kualitas laporan keuangan. Dan pemanfaatan teknologi informasi, kompetensi sumber daya manusia secara parsial berpengaruh signifikan terhadap sistem pengendalian intern. Namun pemahaman sistem akuntansi keuangan daerah berpengaruh tidak signifikan terhadap sistem pengendalian intern
\end{abstract}

Kata kunci: Pemanfaatan teknologi informasi, pemahaman sistem akuntansi keuangan daerah, kompetensi sumber daya manusia, sistem pengendalian intern dan kualitas laporan keuangan.

Abstract: The objective of the research was to analyze the influence of using of information technology, understanding regional government accounting system, human resources competence on the quality of financial report and to examine and analyze internal control system in intervening the correlation of using of information technology, understanding regional government accounting system, human resources competence on the quality of financial report. The research used a quantitative approach. Data used in this research are primary data. It also used survey approach by distributing questionnaires to regional financial personnel in the Riau Islands Provincial Government. The population was 123 financial personnel at 41 OPDs, and the samples were taken by using census sampling technique. The data were processed by using SEM-PLS version 3.0. The result of the research showed that partially using of information technology, understanding regional government accounting system, human resources competence and internal control system had significant influence on the quality of financial report. And using of information technology, human resources competence partially Internal control system was able to intervening the correlation of regional government accounting system, financial administration, human resources competence with the performance of regional financial personnel.

Keywords: Using of information technology, understanding regional government accounting system, human resources competence, internal control system and quality of financial report. 


\section{PENDAHULUAN}

Undang-Undang Nomor 17 tahun 2003 tentang Keuangan Negara dan UndangUndang Nomor 32 Tahun 2004 tentang Pemerintah Daerah mengatur bentuk pertanggungjawaban dalam penyelenggaraan pemerintahan. Undang-Undang ini menegaskan bahwa perlu upaya yang nyata untuk mewujudkan transparansi dan akuntabilitas pengelolaan keuangan pemerintah, baik pemerintah pusat maupun pemerintah daerah.

Peraturan Pemerintah tentang Pengelolaan Keuangan Daerah mengamanatkan bahwa keuangan daerah agar dikelola secara tertib, taat pada peraturan perundang-undangan, efisien, ekonomis, efektif, transparan, dan bertanggung jawab dengan memperhatikan asas keadilan, kepatutan, dan manfaat untuk masyarakat.

Bentuk laporan pertanggungjawaban atas pengelolaan keuangan daerah selama satu tahun anggaran adalah dalam bentuk Laporan Keuangan Pemerintah Daerah (LKPD). Laporan keuangan pemerintah daerah harus mengikuti Standar Akuntansi Pemerintahan sesuai Peraturan Pemerintah No. 71 Tahun 2010. Tujuan diberlakukan-nya hal tersebut adalah agar lebih meningkatkan akuntabilitas dan semakin diperlukannya peningkatan kualitas informasi laporan keuangan.

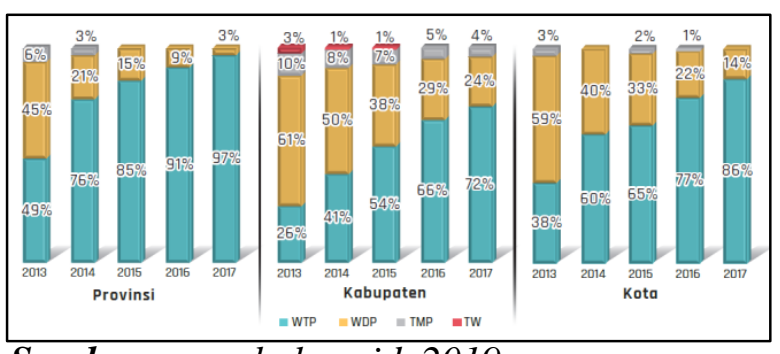

Sumber: www.bpk.go.id, 2019

\section{Grafik 1}

Opini LKPD Tahun 2013-2017 Berdasarkan Tingkat Pemerintah Daerah

Dari grafik 1 tersebut terlihat perkembangan opini LKPD berdasarkan tingkat pemerintah daerah Provinsi, Kabupaten, Kota dari tahun 2013 sampai dengan 2017. Capaian opini tersebut telah melampaui target kinerja keuangan daerah bidang penguatan tata kelola pemerintah daerah/program peningkatan kapasitas keuangan pemerintah provinsi, kabupaten, dan kota yang ditetapkan dalam RPJMN 2015-2019 masing-masing sebesar 85\%, 60\%, dan $65 \%$ di tahun 2019.

Capaian opini tersebut bukan berarti tanpa catatan-catatan yang berupa temuan-temuan. Hampir seluruh pemerintah daerah mendapatkan catatan-catatan berupa temuantemuan meskipun temuan-temuan tersebut tidak berpengaruh langsung terhadap kewajaran LKPD masing-masing pemerintah provinsi, kabupaten dan kota tahun Anggaran 2017 namun hal tersebut harus segera ditindaklanjuti untuk dapat menghasilkan laporan keuangan yang berkualitas.

Berdasarkan pemeriksaan atas Laporan Keuangan Pemerintah Provinsi Kepulauan Riau tahun anggaran 2017, Badan Pemeriksa Keuangan Perwakilan Provinsi Kepulauan 
Riau menemukan beberapa permasalahan dalam pengelolaan keuangan yang dilakukan oleh Pemerintah Provinsi Kepulauan Riau. Permasalahan yang ditemukan antara lain terkait Sistem Pengendalian Intern dan terkait kepatuhan terhadap peraturan perundangundangan seperti berikut ini :

1. Terdapat dana beasiswa yang belum tersalurkan sebesar Rp.1,98 miliar dan terdapat sisa kas yang terlambat disetorkan ke kas daerah sebesar Rp.158,50 juta.

2. Terdapat investasi pemerintah Provinsi Kepulauan Riau yang tidak memberikan manfaat ekonomi sebesar Rp.43,41 miliar.

3. Terdapat realisasi belanja jasa publikasi pada Dinas Pendidikan Provinsi Kepulauan Riau yang masih menggunakan media yang belum terverifikasi oleh dewan pers sebesar Rp.390,65 juta.

4. Terdapat kekurangan dan kelebihan atas penerimaan pajak kendaraan bermotor dan bea balik nama kendaraan bermotor tahun 2013, masing-masing sebesar Rp.4,95 miliar dan Rp.10,81 miliar. (www.bpk.go.id)

Masalah tersebut selain disebabkan oleh faktor-faktor yang berhubungan langsung dengan penyusunan laporan keuangan masih ada faktor-faktor lainnya yang juga ikut mempengaruhi kualitas laporan keuangan diantaranya pemanfaatan teknologi informasi, pemahaman Sistem Akuntansi Keuangan Daerah, kompetensi Sumber Daya Manusia (SDM), penerapan dan pelaksanaan Sistem Pengendalian Intern (SPI).
Fenomena yang terjadi diantaranya Aparatur Sipil Negara (ASN) di Lingkungan Pemerintah Provinsi Kepulauan Riau masih banyak yang kurang memahami Sistem Akuntansi Keuangan Daerah (SAKD). Dari sisi teknologi informasi seringkali ditemukan dilapangan bahwa begitu minimnya aparatur yang ada dipemerintah daerah yang memahami dalam pengaplikasian teknologi informasi. Selain itu adanya perkembangan teknologi informasi yang kedepan diprediksi akan bertambah baik dan terus mengikuti perkembangan zaman menyebabkan fasilitasfasilitas penunjang pemanfaatan teknologi informasi harus terus dikembangkan dan dilengkapi agar tidak tertinggal namun kenyataannya fasilitas-fasilitas pemanfaatan teknologi informasi tersebut ternyata masih belum maksimal dalam pemenuhannya.

Dilihat dari sisi kualitas sumber daya manusia, masih dinilai kurang memadai yang mana dilihat dari latar belakang pendidikan yang tidak sesuai dengan bidang pekerjaannya. Sementara pada Sistem Pengendalian Intern (SPI) dinilai masih belum stabil penerapannya.

Berdasarkan beberapa fenomena tersebut menyimpulkan bahwa laporan keuangan yang dihasilkan oleh pemerintah daerah masih belum memenuhi kriteria nilai informasi yang disyaratkan.

Tujuan yang ingin dicapai dalam penelitian ini adalah:

1. Untuk mengetahui pengaruh pemanfaatan teknologi informasi terhadap kualitas 
laporan keuangan pada Pemerintah Provinsi Kepulauan Riau?

2. Untuk mengetahui pengaruh pemahaman sistem akuntansi keuangan daerah terhadap kualitas laporan keuangan pada Pemerintah Provinsi Kepulauan Riau?

3. Untuk mengetahui pengaruh kompetensi sumber daya manusia terhadap kualitas laporan keuangan pada Pemerintah Provinsi Kepulauan Riau?

4. Untuk mengetahui pengaruh sistem pengendalian internal terhadap kualitas laporan keuangan pada Pemerintah Provinsi Kepulauan Riau?

5. Untuk mengetahui pengaruh pemanfaatan teknologi informasi terhadap sistem pengendalian internal pada Pemerintah Provinsi Kepulauan Riau?

6. Untuk mengetahui pengaruh pemahaman sistem akuntansi keuangan daerah terhadap sistem pengendalian internal pada Pemerintah Provinsi Kepulauan Riau?

7. Untuk mengetahui pengaruh kompetensi sumber daya manusia terhadap sistem pengendalian internal pada Pemerintah Provinsi Kepulauan Riau?

Adapun Hipotesis dalam penelitian ini adalah:

1. Pemanfaatan teknologi informasi berpengaruh terhadap kualitas laporan keuangan.

2. Pemahaman sistem akuntansi keuangan daerah berpengaruh terhadap kualitas laporan keuangan.

3. Kompetensi sumber daya manusia berpengaruh terhadap kualitas laporan keuangan.

4. Sistem pengendalian intern berpengaruh terhadap kualitas laporan keuangan.

5. Pemanfataan teknologi informasi berpengaruh terhadap sistem pengendalian intern.

6. Pemahaman sistem akuntansi keuangan daerah berpengaruh terhadap sistem pengendalian intern.

7. Kompetensi sumber daya manusia berpengaruh terhadap sistem pengendalian intern.

Menurut Heri (2015:5) laporan keuangan pada dasarnya adalah hasil dari proses akuntansi yang dapat digunakan sebagai alat untuk mengkomunikasikan data keuangan atau aktivitas perusahaan kepada pihak yang berkepentingan.

Menurut Jonas dan Blanchet yang dikutip oleh Yadiati, dkk (2017:2) disebutkan bahwa secara umum pelaporan keuangan yang memenuhi karakteristik kualitatif tersebut adalah pelaporan keuangan yang memenuhi keinginan pengguna. Menurut Sulistiyowati (2013) ada empat karakteristik kualitatif laporan keuangan yaitu (1) dapat dipahami, (2) relevan, (3) andal, dan (4) dapat dibandingkan.

Menurut kampus Oxford yang dikutip oleh Rerung (2018:3) teknologi informasi adalah penggunaan peralatan elektronika terutama komputer untuk menyimpan, menganalisis dan mendistribusikan informasi apa saja termasuk kata, bilangan, gambar. Sedangkan 
menurut Eko Indrajit yang dikutip oleh Rerung (2018:3) mendefinisikan teknologi informasi adalah suatu teknologi yang berhubungan dengan pengelolaan data menjadi informasi dan proses penyaluran data atau informasi tersebut dalam batas-batas ruang dan waktu.

Menurut Rasdianto (2013:6) mengata-kan bahwa: "Sistem akuntansi keuangan daerah adalah sistem akuntansi yang meliputi proses pencatatan, penggolongan, penafsiran, peringkasan transaksi atau kejadian keuangan serta pelaporan keuangan dalam rangka pelaksanaan anggaran pendapatan belanja daerah (APBD)"'. Sedangkan Menurut Nordiawan, dkk (2006) mengatakan bahwa: "Sistem akuntansi pemerintah daerah adalah serangkaian prosedur mulai dari proses pengumpulan data, pencatatan, pengikhtisaran, sampai dengan pelaporan keuangan, dalam rangka pertanggung-jawaban pelaksanaan anggaran pendapat-an belanja daerah (APBD) yang dapat dilakukan secara manual atau meng-gunakan aplikasi komputer".

Menurut Marwansyah

(2009:36) kompetensi adalah perpaduan pengetahuan, keterampilan, sikap dan karakteristik pribadi lainnya yang diperlukan untuk mencapai keberhasilan dalam sebuah pekerjaan, yang diukur menggunakan standar yang telah disepakati dan yang dapat ditingkatkan melalui pelatihan dan pengembangan.

Suprapto dalam Nurhayati (2016:24) berpendapat bahwa standar kompetensi minimal mengandung empat komponen pokok, yaitu: (a) pengetahuan; keterampilan; (c) perilaku dan (d) kemampuan untuk mengembangkan pengetahuan dan keterampilan kepada orang lain.

\section{METODE PENELITIAN}

Penelitian ini menggunakan pende-katan kuantitatif dengan mengkaji fakta-fakta yang telah terjadi serta semua data dan informasi diwujudkan dalam bentuk angka, dengan analisis statistik parametrik. Informasi yang menyangkut variable dalam penelitian ini diperoleh dari responden yang ditransfer dalam bentuk angka-angka kemudian dianalisis dengan program SEM-PLS. Analisis yang digunakan adalah regresi sederhana dan regresi ganda.

Penelitian ini dilakukan pada seluruh Organisasi Perangkat Daerah (OPD) pada Pemerintah Provinsi Kepulauan Riau dengan waktu penelitian dilakukan mulai bulan Maret sampai dengan bulan Juli 2019. Unit analisis pada penelitian ini dilakukan pada tingkat organisasi.

Populasi dalam penelitian ini adalah seluruh Organisasi Perangkat Daerah (OPD) yang ada di Provinsi Kepulauan Riau yaitu berjumlah 41 OPD yang terdiri dari 6 (enam) Badan, 21 (dua puluh satu) Dinas, 9 (sembilan) Biro, 1 (satu) Sekretariat DPRD, 1 (satu) Satuan Polisi Pamong Praja, 1 (satu) Inspektorat, dan 2 (dua) RSU. Untuk masingmasing OPD tersebut, penyebaran kuesioner terfokus terhadap 3 orang yaitu kepala sub bagian keuangan, bendahara pengeluaran dan 
pembantu bendahara pengeluaran dengan total 123 orang responden. Penelitian ini menggunakan teknik sensus atau sampel jenuh artinya seluruh populasi akan penulis jadikan sampel. Jumlah populasi yang akan digunakan sebanyak 123 orang responden.

Teknik pengumpulan data yang dilakukan adalah melalui teknik observasi, kuesioner dan studi pustaka. Sementara teknik analisis data menggunakan software Smart PLS versi 3 yang dijalankan dengan media komputer. Masing-masing hipotesis akan dianalisis menggunakan SmartPLS versi 3 untuk menguji hubungan antar variabel.

Dalam penelitian ini variabel bebas adalah Pemanfaatan Teknologi Informasi (X1), Pemahaman Sistem Akuntansi Keuangan Daerah (X2), Kompetensi Sumber Daya Manusia (X3), sementara variabel terikatnya adalah Kualitas Laporan Keuangan (Y), kemudian variabel intervening dalam penelitian ini adalah Sistem Pengendalian Intern (X4). Kesemua variabel ini disajikan berupa kuesioner yan disebarkan dengan scoring model yang skala Likert yang diisi oleh responden.

Secara umum teknik dalam pemberian skor yang digunakan dalam kuesioner penelitian ini adalah teknik skala Likert. Penggunaan skala Likert menurut Sugiyono (2013:132) adalah "skala Likert digunakan untuk mengukur sikap, pendapat dan persepsi seseorang atau sekelompok orang tentang fenomena sosial". Kuesioner menggunakan skala sikap "likert" dengan skala ukur interval dengan skor 1 sampai dengan 5 . Pernyataan/pertanyaan yang mendukung masing-masing variabel diukur dengan memberi skor : 5 (SS=sangat setuju), skor 4 ( $\mathrm{S}=$ setuju), skor 3 ( $\mathrm{N}=$ netral/R=ragu-ragu $)$, skor 2 (TS=tidak setuju), dan skor 1 (STS=sangat tidak setuju).

\section{HASIL DAN PEMBAHASAN}

Tabel 1

Path Coefficients

\begin{tabular}{|c|l|l|l|l|l|}
\hline & $\begin{array}{c}\text { Original } \\
\text { Sample }\end{array}$ & $\begin{array}{c}\text { Sample } \\
\text { Mean }\end{array}$ & $\begin{array}{c}\text { Standard } \\
\text { Deviation }\end{array}$ & $\begin{array}{c}\text { T } \\
\text { Statistics }\end{array}$ & $\begin{array}{c}\mathbf{P} \\
\text { Values }\end{array}$ \\
\hline $\begin{array}{c}\text { X1 -> } \\
\text { X4 }\end{array}$ & 0,334 & 0,334 & 0,063 & 5,308 & 0,000 \\
\hline $\begin{array}{c}\text { X1 -> } \\
\text { Y }\end{array}$ & 0,281 & 0,280 & 0,043 & 6,480 & 0,000 \\
\hline $\begin{array}{c}\text { X2 -> } \\
\text { X4 }\end{array}$ & $-0,001$ & 0,006 & 0,107 & 0,013 & 0,990 \\
\hline $\begin{array}{c}\text { X2 -> } \\
\text { Y }\end{array}$ & 0,239 & 0,238 & 0,045 & 5,279 & 0,000 \\
\hline $\begin{array}{c}\text { X3 -> } \\
\text { X4 }\end{array}$ & 0,556 & 0,555 & 0,121 & 4,597 & 0,000 \\
\hline $\begin{array}{c}\text { X3 -> } \\
Y\end{array}$ & 0,197 & 0,198 & 0,049 & 3,986 & 0,000 \\
\hline $\begin{array}{c}\text { X4 -> } \\
Y\end{array}$ & 0,432 & 0,429 & 0,051 & 8,544 & 0,000 \\
\hline
\end{tabular}

Sumber: Hasil Olahan, 2019

Pengaruh Pemanfaatan Teknologi Informasi Terhadap Kualitas Laporan Keuangan

Berdasarkan nilai t statistik pada tabel 1 diatas pemanfaatan teknologi informasi dengan kualitas laporan keuangan memiliki nilai $P$ value $0,000<0,05$ dengan $\mathrm{t}$ statistik sebesar $6,480>1,96$, maka pemanfaatan teknologi informasi (X1) memiliki pengaruh yang signifikan terhadap kualitas laporan keuangan (Y).

Makna dari temuan penelitian ini menunjukkan bahwa terdapat hubungan antara pemanfaatan teknologi informasi dengan 
kualitas laporan keuangan di Pemerintah Provinsi Kepulauan Riau. Dari hasil pengumpulan data kuesioner yang disebarkan dapat disimpulkan bahwa mayoritas responden "sangat setuju" bahwa pemanfaatan teknologi informasi mampu meningkatkan kualitas laporan keuangan di Pemerintah Provinsi Kepulauan Riau.

Hal ini tergambar dari mayoritas jawaban responden yang menyatakan bahwa pemanfaatan teknologi informasi sangat diperlukan untuk mendukung terciptanya kualitas laporan keuangan yang ditempuh dengan cara penggunaan software aplikasi untuk melaksanakan tugas pembuatan laporan keuangan, dimana software tersebut harus sesuai dengan peraturan perundang- undangan yang berlaku, dukungan jaringan internet dalam proses penggunaan software tersebut untuk memaksimalkan pemanfaatan software, selain itu jaringan internet juga digunakan sebagai penghubung antar unit kerja dalam pengiriman data dan informasi, selain itu implementasi sistem informasi akuntansi untuk memudahkan proses komunikasi antar devisi atau bagian dalam organisasi.

Hasil penelitian ini sejalan dengan penelitian yang dilakukan oleh Harahap (2016) yang membuktikan dalam penelitiannya bahwa pemanfaatan teknologi informasi berpengaruh terhadap kualitas informasi laporan keuangan pada Pemerintah Provinsi Kepulauan Riau. Hasil penelitian ini juga sejalan dengan hasil penelitian Rahmayani (2018) yang menyatakan bahwa pemanfaatan teknologi informasi berpengaruh positif dan signifikan terhadap kualitas laporan keuangan pada Satker Kementrian Agama Mitra Kerja Kantor Pelayanan Perbendaharaan Negara Tebing Tinggi.

\section{Pengaruh Pemahaman Sistem Akuntansi Keuangan Daerah Terhadap Kualitas Laporan Keuangan}

Berdasarkan nilai $\mathrm{t}$ statistik pada tabel 1 diatas pemahaman sistem akuntansi keuangan daerah dengan kualitas laporan keuangan memiliki nilai $P$ value $0,000<0,05$ dengan $\mathrm{t}$ statistik sebesar 5,279 $>1,96$ maka pemahaman sistem akuntansi keuangan daerah (X2) berpengaruh signifikan terhadap kualitas laporan keuangan $(\mathrm{Y})$.

Makna dari temuan penelitian ini menunjukkan bahwa terdapat hubungan antara pemahaman sistem akuntansi keuangan daerah dengan kualitas laporan keuangan di Pemerintah Provinsi Kepulauan Riau. Dari hasil pengumpulan data kuesioner yang disebarkan dapat disimpulkan bahwa mayoritas responden "setuju" bahwa pemahaman sistem akuntansi keuangan daerah mampu meningkatkan kualitas laporan keuangan di Pemerintah Provinsi Kepulauan Riau.

Hal ini tergambar dari mayoritas jawaban responden yang menjawab setuju bahwa pembuat laporan keuangan harus memiliki pemahaman sistem akuntansi keuangan daerah yang meliputi pemahaman terkait sistem dan prosedur akuntansi penerimaan kas, pengeluaran kas, aset dan selain kas, selain itu pemahaman terhadap sistem pencatatan 
transaksi keuangan melalui prosedur pencatatan double entry juga harus dimiliki, pemahaman yang baik tentang prosedur akuntansi berbasis akrual yang harus dilakukan dalam penyusunan laporan keuangan sesuai dengan PP 71 tahun 2010 yang merupakan dasar dalam pembuatan laporan keuangan pemerintah daerah juga harus dimiliki oleh pembuat laporan keuangan.

Temuan peneliti ini membuktikan bahwa mayoritas responden berpendapat bahwa pemahaman sistem akuntansi keuangan daerah mendukung peningkatan kualitas laporan keuangan, salah satu alasannya dikarenakan setiap entitas organisasi pembuat laporan keuangan yang telah dilengkapi dengan penggunaan aplikasi untuk pelaksanaan pembuatan laporan keuangan harus juga memiliki pemahaman dalam prosedur sistem akuntansi keuangan daerahnya.

Hasil penelitian ini sejalan dengan penelitian yang dilakukan oleh Ponamon (2014) membuktikan dalam penelitiannya bahwa pemahaman sistem akuntansi keuangan berpengaruh terhadap kualitas informasi laporan keuangan pada SKPD Pemerintah Kota Manado. Namun bertolakbelakang dengan hasil penelitian Barus (2017) yang menyatakan bahwa pemahaman sistem akuntansi keuangan daerah tidak berpengaruh terhadap kualitas laporan keuangan pada Pemerintah Kota Binjai.
Pengaruh Kompetensi Sumber Daya Manusia Terhadap Kualitas Laporan Keuangan

Berdasarkan nilai t statistik pada tabel 1 diatas kompetensi sumber daya manusia dengan kualitas laporan keuangan memiliki nilai $\mathrm{P}$ value $0,000<0,05$ dengan $\mathrm{t}$ statistik sebesar 3,986 > 1,96 maka kompetensi sumber daya manusia (X3) memiliki pengaruh yang signifikan terhadap kualitas laporan keuangan (Y).

Makna dari temuan penelitian ini menunjukkan bahwa terdapat hubungan antara kompetensi sumber daya manusia dan kualitas laporan keuangan di Pemerintah Provinsi Kepulauan Riau. Dari hasil pengumpulan data kuesioner yang disebarkan dapat disimpulkan bahwa mayoritas responden "setuju" bahwa kompetensi sumber daya manusia mampu meningkatkan kualitas laporan keuangan di Pemerintah Provinsi Kepulauan Riau.

Hal ini tergambar dari mayoritas jawaban responden yang menyatakan "setuju" bahwa pembuat laporan keuangan di Pemerintah Provinsi Kepulauan Riau yang dalam hal ini PPK-OPD, Bendahara, staf pembantu bendahara rata-rata telah memahami tugas pokok, fungsi dan uraian tugas, telah memiliki pemahaman teknis pekerjaan, sering mambaca literature berupa jurnal akuntansi dan bukubuku akuntansi dalam rangka meningkatkan pengetahuan dibidang akuntansi, mampu membuat jurnal dan memposting jurnal kedalam buku besar untuk setiap transaksi dengan benar, mampu menyusun dan 
menyajikan neraca dengan baik, mampu menyusun dan menyajikan Laporan Realisasi Anggaran serta Catatan atas laporan keuangan dengan baik. Hal ini membuktikan bahwa kompetensi sumber daya manusia merupakan kunci keberhasilan peningkatan kualitas laporan keuangan.

Hasil penelitian yang mendukung tentang pengaruh kompetensi sumber daya manusia terhadap kualitas laporan keuangan dilakukan oleh Nurhayati (2016) dengan hasil kompetensi sumber daya manusia berpengaruh positif terhadap kualitas laporan keuangan pada Pemerintah Provinsi Kepulauan Riau. Selain itu juga sejalan dengan penelitian yang dilakukan oleh Nasution (2017) menemukan hasil bahwa kompetensi sumber daya manusia berpengaruh positif dan signifikan terhadap kualitas laporan keuangan pada Pemerintah Provinsi Sumatera Utara.

\section{Pengaruh Sistem Pengendalian Intern Terhadap Kualitas Laporan Keuangan}

Berdasarkan nilai $\mathrm{t}$ statistik pada tabel 1 diatas sistem pengendalian intern dengan kualitas laporan keuangan memiliki nilai $\mathrm{P}$ value $0,000<0,05$ dengan $t$ statistik sebesar $8,544>1,96$ menunjukkan bahwa sistem pengendalian intern (X4) memiliki pengaruh yang signifikan terhadap kualitas laporan keuangan (Y).

Interpretasi dari temuan penelitian ini menunjukkan bahwa terdapat hubungan antara sistem pengendalian intern dan kualitas laporan keuangan pada Pemerintah Provinsi
Kepulauan Riau. Hal ini menandakan kualitas laporan keuangan didukung oleh audit melalui sistem pengendalian intern, artinya dengan adanya sistem pengendalian intern maka terjadi peningkatan kualitas laporan keuangan, sekalipun belum optimal. Hasil penelitian ini sejalan dengan penelitian yang dilakukan oleh Girsang (2017) dengan hasil sistem pengendalian intern berpengaruh signifikan terhadap kualitas laporan keuangan Pemerintah Kabupaten Samosir. Selain itu juga sejalan dengan penelitian yang dilakukan oleh Manullang (2016) menemukan hasil bahwa sistem pengendalian intern berpengaruh signifikan terhadap kualitas laporan keuangan pada Pemerintah Kota Tebing Tinggi.

\section{Pengaruh Pemanfaatan Teknologi Informasi Terhadap Sistem Pengendalian Intern}

Berdasarkan nilai t statistik pada tabel 1 diatas pemanfaatan teknologi informasi dengan sistem pengendalian intern memiliki nilai $\mathrm{P}$ value $0,000<0,05$ dengan $\mathrm{t}$ statistik sebesar 5,308>1,96 maka pemanfaatan teknologi informasi (X1) memiliki pengaruh yang signifikan terhadap sistem pengendalian intern (X4).

Makna dari temuan penelitian ini menunjukkan bahwa terdapat hubungan antara pemanfaatan teknologi informasi terhadap sistem pengendalian intern di Pemerintah Provinsi Kepulauan Riau. Hal ini membuktikan bahwa pemanfaatan teknologi informasi akan memperkuat sistem 
pengendalian intern yang berbasis pemanfaatan teknologi.

Pemprov Kepri menggunakan program sistem informasi manajemen keuangan daerah (SIMDA) yang didalamnya terdapat sub sistem, tahap-tahap, prosedur, perangkat dan peraturan yang harus diikuti dalam rangka mengumpulkan dan mencatat data keuangan untuk menghasilkan laporan keuangan dimana sistem tersebut dibentuk dengan berdasarkan prinsip-prinsip sistem pengendalian intern. Jadi pada prinsipnya bahwa perkembangan zaman saat ini yang juga menghadirkan perkembangan teknologi informasi harus mampu dimanfaatkan secara optimal dalam mewujudkan peningkatan kualitas laporan keuangan pemerintah daerah melalui sistem pengendalian intern yang berbasis pemanfaatan teknologi.

Hasil penelitian ini sejalan dengan penelitian yang dilakukan oleh Utomo dalam Amanda (2016:11) dengan hasil penerapan teknologi informasi yang melalui tahap pengolahan data secara komputerisasi (Electronic Data Processing/EDP) dapat memberikan dampak terhadap proses auditing dan juga berpengaruh pada pengendalian internal sebuah perusahaan atau organisasi. Selain itu juga sejalan dengan penelitian yang dilakukan oleh Amanda (2016) dengan hasil auditor lebih memilih menggunakan Electronic Data Processing (EDP) dalam proses pengendalian internal pada Bank BRI Wilayah Surabaya. 
Sistem Pengendalian Intern yang diterapkan di Pemerintah Provinsi Kepulauan Riau yang dalam hal ini dilakukan oleh Inspektorat Provinsi Kepulauan Riau tidak pernah mempertanyakan tentang pemahaman sistem akuntansi keuangan daerah kepada PPK-OPD, Bendahara, dan staf pembantu bendahara melainkan hanya terfokus kepada hasil akhir laporan keuangan, hal ini disebabkan karena dalam proses pembuatan laporan keuangan menggunakan aplikasi dimana responden hanya mengentry data transaksi keuangan. Pemahaman sistem akuntansi keuangan daerah responden terutama PPK-OPD dinilai kurang karena dalam penempatan pejabat yang akan menduduki jabatan sebagai PPK-OPD tidak didasarkan pada kualifikasi pendidikan yang sesuai sehingga pemahaman sistem akuntansi keuangan daerahnya kurang baik.

Hasil penelitian ini sejalan dengan hasil penelitian yang dilakukan oleh Putri, dkk (2016) dengan hasil sistem akuntansi keuangan daerah tidak berpengaruh terhadap sistem pengendalian internal pada SKPD Kota Pekanbaru, Kampar dan Rokan Hilir. Namun bertolakbelakang dengan hasil penelitian widyaningsih, dkk (2011) dengan hasil hubungan yang kuat antara efektivitas sistem akuntansi keuangan daerah dan sistem pengendalian internal, dan bahwa efektivitas sistem akuntansi keuangan daerah memiliki pengaruh signifikan terhadap sistem pengendalian internal pada Pemerintah Daerah Kabupaten/Kota Provinsi Jawa Barat.

\section{Pengaruh Kompetensi Sumber Daya Manusia Terhadap Sistem Pengendalian Intern}

Berdasarkan nilai $\mathrm{t}$ statistik pada tabel 1 diatas kompetensi sumber daya manusia dengan sistem pengendalian intern memiliki nilai $\mathrm{P}$ value $0,000<0,05$ dengan $\mathrm{t}$ statistik sebesar 4,597 > 1,96 maka kompetensi sumber daya manusia (X3) memiliki pengaruh yang signifikan terhadap sistem pengendalian intern (X4).

Makna dari temuan penelitian ini menunjukkan bahwa terdapat hubungan antara kompetensi sumber daya manusia dengan sistem pengendalian intern di Pemerintah Provinsi Kepulauan Riau. Kompetensi sumber daya manusia yang tinggi dalam menerapkan sistem pengendalian internal secara optimal, akan mampu meningkatkan kualitas laporan keuangan pemerintah. Sistem Pengendalian Intern yang dijalankan oleh PPK-OPD yang memiliki kompetensi, akan mampu menghasilkan laporan keuangan pemerintah daerah yang memenuhi karakteristik relevan, andal, dapat diperbandingkan dan dapat dipahami. (Sudiarianti, Ulupui and Budiasih, 2015).

Dilihat dari hubungannya terhadap sumber daya manusia yang terkait dalam proses pengendalian internalnya maka hubungan kompetensi SDM memiliki pengaruh yang signifikan terhadap efektifitas penerapan Sistem Pengendalian Intern Pemerintah artinya semakin tinggi variasi kompetensi SDM maka pengendalian internal pemerintah akan semakin efektif. Dengan demikian 
kompetensi aparatur sangat berpengaruh terhadap peningkatan kinerja dan ketaatan terhadap aturan dalam melaksanakan kegiatan pemerintahan.

Hasil penelitian ini sejalan dengan penelitian Sudiarianti, Ulupui, Budiasih (2015) dengan hasil kompetensi sumber daya manusia berpengaruh positif terhadap sistem pengendalian internal pemerintah (SPIP) pada Pemerintah Daerah Kabupaten Tabanan.

Tabel 2

Total Indirect Effect

\begin{tabular}{|c|c|c|c|c|c|}
\hline & $\begin{array}{l}\text { Origina } \\
\text { Sample }\end{array}$ & $\begin{array}{c}\text { Sample } \\
\text { Mean }\end{array}$ & \begin{tabular}{|l|} 
Standard \\
Deviation
\end{tabular} & $\begin{array}{c}T \\
\text { Statistics }\end{array}$ & \begin{tabular}{|c|}
$\mathbf{P}$ \\
Values
\end{tabular} \\
\hline $\begin{array}{c}\mathrm{X} 1 \text {-> } \\
\text { X4 }\end{array}$ & & & & & \\
\hline $\begin{array}{c}\mathrm{X} 1 \text {-> } \\
\mathrm{Y}\end{array}$ & 0.144 & 0.144 & 0.033 & 4.398 & 0.000 \\
\hline $\begin{array}{c}\mathrm{X} 2-> \\
\mathrm{X} 4\end{array}$ & & & & & \\
\hline $\begin{array}{c}\mathrm{X} 2 \text {-> } \\
\mathrm{Y}\end{array}$ & $-0,001$ & 0.004 & 0.045 & 0.013 & 0.990 \\
\hline $\begin{array}{c}\text { X3 -> } \\
\text { X4 }\end{array}$ & & & & & \\
\hline $\begin{array}{c}\text { X3 -> } \\
\text { Y }\end{array}$ & 0.240 & 0.237 & 0.052 & 4.574 & 0.000 \\
\hline $\begin{array}{c}\mathrm{X} 4 \text {-> } \\
\mathrm{Y}\end{array}$ & & & & & \\
\hline
\end{tabular}

Sumber: Hasil Olahan, 2019

Berdasarkan nilai original sample, $\mathrm{P}$ Value dan $t$ statistic pada tabel 2 dapat diuji hipotesis sebagai berikut :

1. Pengaruh tidak langsung variabel pemanfaatan teknologi informasi (X1) $\rightarrow$ sistem pengendalian intern (X4) $\rightarrow$ kualitas laporan keuangan (Y) dibuktikan dengan nilai $P$ value $0,000<0,05$ dengan t statistik sebesar 4,398 > 1,96 maka hasilnya adalah signifikan (pengaruhnya adalah tidak langsung) artinya variabel "intervening" yaitu sistem pengendalian intern (X4) mampu berperan dalam mengantarai/memediasi hubungan antara variabel pemanfaatan teknologi informasi (X1) dengan variabel kualitas laporan keuangan (Y).

2. Pengaruh tidak langsung variabel pemahaman sistem akuntansi keuangan daerah $(\mathrm{X} 2) \rightarrow$ sistem pengendalian intern $(\mathrm{X} 4) \rightarrow$ kualitas laporan keuangan (Y) dibuktikan dengan nilai $P$ value $0,990>$ 0,05 dengan $t$ statistik sebesar $0,013<1,96$ maka hasilnya adalah tidak signifikan artinya variabel "intervening" yaitu sistem pengendalian intern (X4) tidak mampu berperan dalam mengantarai/memediasi hubungan antara variabel pemahaman sistem akuntansi keuangan daerah (X2) dengan variabel kualitas laporan keuangan (Y).

3. Pengaruh tidak langsung kompetensi sumber daya manusia (X3) $\rightarrow$ sistem pengendalian intern (X4) $\rightarrow$ kualitas laporan keuangan (Y) dibuktikan dengan nilai $P$ value $0,000<0,05$ dengan $\mathrm{t}$ statistik sebesar 4,574>1,96 maka hasilnya adalah signifikan (pengaruhnya adalah tidak langsung) artinya variabel “intervening" yaitu sistem pengendalian intern (X4) mampu berperan dalam mengantarai/memediasi hubungan antara variabel kompetensi sumber daya manusia (X3) dengan variabel kualitas laporan keuangan (Y). 


\section{PENUTUP}

\section{Kesimpulan}

Berdasarkan hasil analisis data, pengujian hipotesis dan hasil temuan deskriptif dari kuesioner, maka dapat disimpulkan sebagai berikut :

1. Pemanfaatan teknologi informasi (X1) memiliki pengaruh yang signifikan terhadap kualitas laporan keuangan (Y).

2. Pemahaman sistem akuntansi keuangan daerah (X2) berpengaruh signifikan terhadap kualitas laporan keuangan (Y).

3. Kompetensi sumber daya manusia (X3) memiliki pengaruh yang signifikan terhadap kualitas laporan keuangan (Y).

4. Sistem pengendalian intern (X4) memiliki pengaruh yang signifikan terhadap kualitas laporan keuangan (Y).

5. Pemanfaatan teknologi informasi (X1) memiliki pengaruh yang signifikan terhadap sistem pengendalian intern (X4).

6. Pemahaman sistem akuntansi keuangan daerah (X2) berpengaruh tidak signifikan terhadap sistem pengendalian intern (X4).

7. Kompetensi sumber daya manusia (X3) memiliki pengaruh yang signifikan terhadap sistem pengendalian intern (X4).

8. Variabel "intervening" yaitu sistem pengendalian intern (X4) mampu berperan dalam mengantarai/ memediasi hubungan antara variabel pemanfaatan teknologi informasi (X1) dengan variabel kualitas laporan keuangan (Y).

9. Variabel "intervening" yaitu sistem pengendalian intern (X4) tidak mampu berperan dalam mengantarai/ memediasi hubungan antara variabel pemahaman sistem akuntansi keuangan daerah (X2) dengan variabel kualitas laporan keuangan (Y).

10. Variabel “intervening" yaitu sistem pengendalian intern (X4) mampu berperan dalam mengantarai/ memediasi hubungan antara variabel kompetensi sumber daya manusia (X3) dengan variabel kualitas laporan keuangan $(\mathrm{Y})$.

\section{Saran}

Berdasarkan hasil simpulan yang didapat, maka dapat diberi saran sebagai berikut :

1. Pemerintah Provinsi Kepulauan Riau harus mampu mengoptimalkan berbagai langkah dalam rangka pengembangan dan pemanfaatan kemajuan teknologi informasi demi peningkatan kualitas laporan keuangan.

2. Pemerintah Provinsi Kepulauan Riau diharapkan mampu meningkatkan alokasi anggaran pelatihan/diklat yang terkait dengan pemahaman sistem akuntansi keuangan daerah agar kualitas laporan keuangan dapat ditingkatkan.

3. Pemerintah Provinsi Kepulauan Riau diharapkan mampu meningkatkan alokasi anggaran pelatihan/diklat yang terkait dengan peningkatan kompetensi sumber daya manuasia demi peningkatan kualitas laporan keuangan dimasa mendatang.

4. Pemerintah Provinsi Kepulauan Riau diharapkan lebih mengoptimalkan fungsi 
pengendalian intern demi peningkatan kualitas laporan keuangan.

\section{DAFTAR PUSTAKA}

Amanda, N.S., 2016. Dampak Electronic Data Processing Pada Proses Auditing Dan Pengendalian Internal Bank Bri Wilayah dissertation, STIE PERBANAS SURABAYA).

Barus, S., 2017. Analisis Pengaruh Kompetensi Sumber Daya Manusia, Penerapan Standar Akuntansi Pemerintahan, Sistem Akuntansi Keuangan Daerah dan Pemanfaatan Teknologi Informasi Terhadap Kualitas Laporan Keuangan Pemerintah Kota Binjai Dengan Sistem Pengendalian Internal Pemerintah Sebagai Variabel Moderating.

Girsang, M., 2017. Pengaruh Sistem Pengendalian Intern Pemerintah, Implementasi Standar Akuntansi Pemerintahan, Penyelesaian Temuan Audit, Kompetensi SDM terhadap Kualitas Laporan Keuangan dengan Penerapan Good Governance Sebagai Variabel Moderating pada Pemerintah Kabupaten Samosir.

Harahap, N., 2016. Analisa Faktor-Faktor yang Mempengaruhi Kualitas Laporan Keuangan Pemerintah Provinsi Kepulauan Riau. Tesis. Universitas Batam.

Manullang, O.E., 2016. Analisis FaktorFaktor yang Mempengaruhi Kualitas Laporan Keuangan Pemerintah Daerah pada Pemerintah Kota Tebing Tinggi dengan Komitmen Organisasi sebagai Variabel Moderating.

Marwansyah., 2009. Manajemen Sumber Daya Manusia. Bandung: Alfabeta.

Nasution, F.F., 2017. Pengaruh Kompetensi SDM, Penerapan Aplikasi Keuangan, Penerapan Standar Akuntansi Pemerintahan Terhadap Kualitas Laporan Keuangan Pemerintah Provinsi Sumatera Utara Dengan Komitmen Organisasi Sebagai Variabel Moderating.

Nordiawan, D. and Hertianti, A., 2006.
Akuntansi sektor publik. Jakarta: Salemba Empat.

Nurhayati., 2016. Pengaruh Kompetensi Sumber Daya Manusia, Audit Internal Terhadap Kualitas Laporan Keuangan dengan Variabel Intervening Efektifitas Pengendalian Intern pada Pemerintah Provinsi Kepulauan Riau. Tesis. Universitas Batam.

Ponamon, I.F., 2014. Pengaruh Pengawasan Internal, Pemahaman Sistem Akuntansi Keuangan, Dan Kapasitas Sumber Daya Manusia Terhadap Kualitas Informasi Laporan Keuangan Pemerintah Daerah Pada Skpd Pemerintah Kota Manado. Going Concern: Jurnal Riset Akuntansi, 9(2).

Putri, A.M., Kirmizi, K. and Basri, Y.M., 2016. Pengaruh Penerapan Sistem Akuntansi Keuangan Daerah, Penerapan Standar Akuntansi Pemerintah dan Kompetensi Sumber Daya Manusia Terhadap Kualitas Laporan Keuangan Pemerintah Daerah; Sistem Pengendalian Intern Pemerintah Sebagai Pemediasi. Jurnal Ekonomi, 24(4), p.16.

Rahmayani, S., 2018. Pengaruh Kompetensi Sumber Daya Manusia, Pemanfaatan Teknologi Informasi, dan Rekonsiliasi Data Terhadap Kualitas Laporan Keuangan pada Satuan Kerja Kementerian Agama Mitra Kerja Kantor Pelayanan Perbendaharaan Negara Tebing Tinggi.

Rasdianto, E., 2013. Akuntansi Keuangan Daerah Berbasis Akrual.

Rerung, R.R., 2018. Pemrograman Web Dasar. Deepublish.

Selvia, H., 2015. Praktis Menyusun Laporan Keuangan: cepat dan mahir menyajikan informasi keuangan/Hery.

Sudiarianti, N.M., Ulupui, I.G.K.A. and Budiasih, I.G.A., 2015. Pengaruh Kompetensi Sumber Daya Manusia Pada Penerapan Sistem Pengendalian Intern Pemerintah dan Standar Akuntansi Pemerintah Serta Implikasinya Pada Kualitas Laporan Keuangan Daerah. Simposium Nasional Akuntansi XVIII. 
Sulistiyowati, L., 2013. Panduan Praktis

Memahami Laporan Keuangan. Elex Media Komputindo. 